\title{
PENGELOLAAN PRAKTIK KERJA INDUSTRI PADA PROGRAM KEAHLIAN TEKNIK PEMESINAN SMK SE-KABUPATEN KULON PROGO
}

\author{
Suwarman \\ SMKN 2 Pengasih Kulon Progo \\ suwarman_kp@yahoo.com \\ Pardjono \\ Universitas Negeri Yogyakarta \\ pardjono@uny.ac.id
}

\begin{abstract}
Abstrak
Penelitian ini bertujuan untuk mengungkapkan (1) perencanaan; (2) pelaksanaan; (3) evaluasi pembelajaran; (4) evaluasi program; dan (5) manfaat dari praktik kerja industri. Jenis penelitian adalah survey. Sampel penelitian ditentukan berdasarkan tabel Isaac dan Michael dengan taraf signifikansi 5\%. Analisis data yang digunakan adalah analisis data diskriptif kuantitatif. Hasil penelitian menunjukkan bahwa, aspek perencanaan masuk dalam kategori sangat tinggi dengan skor 89,74 Aspek pelaksanaan menurut persepsi siswa, guru pembimbing dan pembimbing industri, masuk dalam kategori tinggi dengan skor masing-masing 320, 41,43 dan 48,7. Menurut persepsi siswa 19\% guru pembimbing kurang dalam melakukan monitoring. Sebagian industri (47\%) tidak pernah memberikan masukan pada sekolah. Evaluasi pembelajaran dilakukan oleh semua industri. Pada aspek manfaat, siswa merasakan manfaat yang sangat besar dengan skor 340,16, sekolah merasakan manfaat yang besar dengan skor 8,88, dan industri merasakan manfaat yang besar dengan skor 57,5.
\end{abstract}

Kata kunci: praktik kerja industri, program keahlian teknik pemesinan

\section{THE INDUSTRIAL WORK PRACTICUM MANAGEMENT OF THE MACHINERY TECHNICAL SKILL PROGRAM OF SMK KULON PROGO REGENCY}

\begin{abstract}
This study aims to determine (1) the planning; (2) the implementation; (3) learning evaluation; (4) evaluation program; and (5) the benefits of the industrial work practicum. This study used survey method. The determination of the sample number used the sample size determination according to Isaac and Michael with the significance level of 5\%. The data analysis used the descriptive quantitative analysis. The results of the research show that the planning aspects is in the high category with scor is 89,74 .. The aspects of the implementation as perceived by students, teachers/ mentors, and industry mentors are in the high category with mean scors each 320, 41,43 and 48,7. According to the students perception there is less guidance from the counselor (19\%) in monitoring activities of the industrial work practicum. Some of the industries (47\%) never provide input to schools to improve the industrial work practicum. The learning evaluation of the industrial work practicum is performed by all industries. In the benefit aspects of the industrial work practicum, the students get many benefits with scor is 340,16, so do the schools and the industry with scors each 8,88 and 57,5 .
\end{abstract}

Keywords: the industrial work practicum, machinery technical skills program. 


\section{PENDAHULUAN}

Perkembangan ilmu pengetahuan dan teknologi di dunia yang semakin pesat menuntut bangsa kita untuk selalu dapat mengikuti perkembangannya. Perkembangan ilmu pengetahuan dan teknologi tidak lepas dari peranan dunia pendidikan. Oleh karena itu perlu adanya peningkatan mutu pendidikan dalam rangka peningkatan kompetensi peserta didik. Peningkatan kualitas pendidikan berarti meningkatkan kualitas sumber daya manusia. Sumber daya manusia tersebut dibutuhkan dalam rangka pemenuhan kebutuhan tenaga kerja di dunia usaha dan dunia industri untuk mendukung pertumbuhan industrialisasi suatu negara. Peranan pendidikan khususnya pendidikan kejuruan sangatlah diperlukan dalam upaya menumbuhkembangkan potensi-potensi yang dimiliki oleh peserta didik untuk menghadapi berbagai tantangan dimasa sekarang dan masa yang akan datang.

Pendidikan kejuruan merupakan bagian dari sistem pendidikan di berbagai negara. Di Indonesia sebagaimana yang disebutkan dalam Undang-Undang Nomor 20 tahun 2003 tentang Sistem Pendidikan Nasional Pasal 15, menyatakan bahwa "Pendidikan kejuruan merupakan pendidikan yang mempersiapkan peserta didik untuk dapat bekerja dalam bidang tertentu". Tujuan pendidikan kejuruan dipertegas lagi dalam Peraturan Pemerintah Nomor 29 Tahun 1990 pasal 3 ayat 2 yang menyatakan bahwa "Pendidikan menengah kejuruan mengutamakan penyiapan peserta didik untuk memasuki lapangan kerja serta mengembangkan sikap profesional." Sedangkan Rupert Evans (1978) dalam Budi Tri Siswanto (2011: 2). pengertian pendidikan kejuruan menurut United States Conggres (1976) dalam Wardiman Djojonegoro (1998: 34), bahwa pendidikan kejuruan adalah program pendidikan yang secara langsung dikaitkan dengan penyiapan seseorang untuk suatu pekerjaan tertentu atau untuk persiapan karir tambahan seseorang.

Salah satu upaya yang dilakukan pemerintah dalam hal ini Kementerian Pendidikan Nasional untuk menyiapkan sumber daya manusia yang berkualitas adalah dengan membuat kebijakan penyelenggaraan Pendidikan Sistem Ganda (PSG) sebagai salah satu implementasi nyata dari kebijakan link and match. Dipertegas juga dalam struktur kurikulum Sekolah Menengah Kejuruan (SMK) yang menyebutkan bahwa "Beban belajar SMK meliputi kegiatan pembelajaran tatap muka (TM), praktik sekolah (PS), dan kegiatan kerja praktik di dunia usaha/industri (PI)" (Dikmenjur, 2011).

Dalam rangka pelaksanaan PSG program praktik kerja industri merupakan program wajib yang harus dilaksanakan oleh sekolah, khususnya sekolah menengah kejuruan dan diikuti oleh peserta didik, hal ini sesuai dengan Keputusan Mendikbud No.086/u/1993 Bab IV butir C1. Tujuan dari kegiatan praktik kerja industri itu sendiri menurut Direktorat Pembinaan Sekolah Menengah Kejuruan (Dikmenjur, 2008) adalah: 1)Pemenuhan kompetensi sesuai tuntutan Kurikulum 2) Implementasi kompetensi ke dalam dunia kerja, 3) Penumbuhan etos kerja/Pengalaman kerja.

Pendidikan kejuruan bertujuan untuk menghasilkan manusia yang produktif, yakni manusia kerja, bukan manusia beban keluarga, masyarakat, dan bangsanya (Soenaryo, et al. 2002: 17). Hal ini sebagaimana yang dikatakan oleh Finch \& Crunkilton (1999: 250) bahwa sekolah harus bisa menjadi jembatan bagi peserta didik untuk memasuki dunia kerja. Pendidikan kejuruan memiliki beberapa manfaat yaitu:

a. Bagi siswa: 1) peningkatan kualitas diri, 2) peningkatan penghasilan, 3) penyiapan bekal pendidikan lebih lanjut, 4) penyiapan diri agar berguna bagi masyarakat dan bangsa.

b. Bagi dunia kerja: 1) dapat memperoleh tenaga kerja berkualitas tinggi, 2) dapat meringankan biaya usaha, 3) dapat membantu memajukan dan mengem- bangkan usaha.

c. Bagi masyarakat: 1) dapat meningkatkan kesejahteraan masyarakat, 2) dapat meningkatkan produktivitas nasional sehingga dapat meningkatkan penghasilan Negara, 3) dapat mengurangi pengangguran.

Program prakerin disusun bersama antara sekolah dengan dunia kerja dalam rangka memenuhi kebutuhan peserta didik dan sebagai kontribusi dunia kerja terhadap pengem- 
bangan program pendidikan sekolah menengah kejuruan. Keharusan untuk melakukan kerjasama ini, mengharuskan masing-masing pihak untuk saling memahami (Direktorat Pembinaan Sekolah Menengah Kejuruan Dirjen Dikdasmen, 2008:1). Hal ini sesuai dengan karakteristik pembelajaran berbasis kerja bahwa program pelatihan berasal dari kebutuhan dari tempat kerja dan pelajar tidak dikendalikan oleh kurikulum profesional atau aturanaturan lain, pekerjaan ditempat kerja adalah sebagai kurikulum (Boud and Solomon, 2003: 5). Sedangkan Raelin (1997) mengatakan bahwa model pembelajaran berbasis tempat kerja (work based learning) adalah sebuah model pembelajaran komprehensif yang mengintegrasikan antara belajar dan bekerja.

Pelaksanaan Praktek Kerja Industri (prakerin) yang dulu sering disebut pendidikan sistem ganda, SMK sesuai dengan fungsinya mempunyaitanggung jawab menyelenggarakan program pendidikan kejuruan, membekali ketrampilan dasar, dan pengetahuan kejuruan serta pengalaman kerja kepada siswanya. Sedangkan dunia usaha dan dunia industri mempunyai fungsi untuk melatih siswa dalam latihan kejuruan, agar siswa siap memasuki lapangan kerja dunia usaha atau industri. Hal ini sesuai dengan yang apa yang dikemukakan Wardiman (2008: 78) bahwa program pendidikan kejuruan dilakukan di dua tempat, sebagian program yaitu teori dan praktik dasar dilaksanakan di sekolah (SMK) dan sebagian lainnya dilaksanakan di dunia kerja yaitu keahlian produktif yang diperoleh melalui kegiatan bekerja di dunia kerja (praktik kerja industri). Dengan prakerin, sekolah memberikan kesempatan pada peserta didik untuk belajar realita yang sebenarnya. Hanya dengan melalui prakerin yang berkesinambungan peserta didik akan memahami kaitan antara teori yang dipelajari di sekolah dengan materipraktek di industri. Lembaga pendidikan perlu mengembangkan kerjasama dengan industri dalam rangka pendidikan dan pelatihan.

Pernyataan di atas menunjukkan, bahwa antara dunia usaha atau industri dan sekolah menengah kejuruan dapat bekerjasama untuk mencapai tujuan meningkatkan kualitas lulu- san. Namun pengalaman menunjukkan bahwa pendidikan sistem ganda belum berjalan sebagaimana yang diharapkan. SMK yang ada belum secara optimal menjalankan misinya dengan baik. Ini dapat dilihat daribeberapa hasil temuan atau penelitian seperti yang diungkapkan oleh Direktorat Pendidikan Menengah Kejuruan yang menengarai masih terdapat beberapakendala dalam pelaksanaan Praktek kerja industri (Prakerin) yaitu: 1) keragaman kondisi geografis; 2) keragaman tingkat kesiapan dan kemajuan SMK; 3 ) keragaman program SMK; 4) belum adanya alokasi biaya pengembangan sumber daya manusia di industri; 5) belum dimiliki struktur jabatan dan keahlian yang baku pada industri; 6) belum dimilikinya persepsi bahwa PSG atau Praktek Kerja Industri dapat menguntungkan industri yang bersangkutan; dan 7) belum dimilikinya kesadaran oleh industri tentang peningkatan efisiensi, keefektifan dan kualitas.

Usaha meningkatkan kompetensi siswa melalui praktik kerja industri juga masih banyak kendala diantaranya a dalah daya tampung pada DU/DI untuk menerima siswa prakerin masih terbatas sehingga tidak semua siswa SMK dapat ditampung dalam praktek kerja industri sesuai dengan bidangnya. Bila tempat praktik mereka peroleh, faktor lain yang kadang terjadi adalah instruktur di tempat prakerin belum memiliki program sesuai dengan harapan kurikulum, dan kurangnya metodologi yang dimiliki industri dalam memberikan bimbingan tentang pengetahuan sikap, dan perilaku kerja profesional.

Hasil-hasil penelitian mutakhir menyimpulkan bahwa pendekatan Pembelajaran Berbasis Tempat Kerja (PBTK) atau Work Based Learning (WBL) yang dalam kontek pendidikan menengah kejuruan kita disebut Praktik Kerja Industri (Prakerin), memiliki prestasi positif dalam hal prestasi (achievement), motivasi (motivation) dan kelanjutan pendidikan (Continuing education) sebagaimana yang disampaikan Bailey \& Merrit dalam Budi Tri Siswanto (2011: 2). Riset dan studi evaluasi pada WBL menunjukkan adanya korelasi antara luaran (outputs) dan dampak (outcomes) lulusan dengan struktur pembelajaran yang 
sekolah dan industri berikan dalam pengalaman di tempat kerja. Lebih lanjut dikatakan bahwa ketika tujuan program, kurikulum dan pengalaman berbasis tempat kerja dirancang dan diaplikasikan disertai dukungan staf yang memadai dan dievaluasi dengan benar, maka program itu akan berdampak positif.

Pada observasi awal yang penulis lakukan di SMK Negeri 2 Pengasih dan di SMK Negeri 1 Nanggulan, terdapat permasalahan pelaksanaan praktik kerja industri yang hampir sama yaitu adanya kesenjangan antara tujuan pelaksanaan prakerin dengan hasilnya. Sebagian siswa yang kembali dari melaksanakan praktik kerja industri yang seharusnya memiliki prestasi dan motivasi justru membawa efek yang kurang baik, seperti malas masuk sekolah dan menurunnya motivasi belajar. Wahyu Nurharjadmo (2008: 227) menemukan dalam penelitiannya bahwa diantara hambatan pelaksanaan praktik kerja industri yang bersumber dari siswa adalah kurangnya keseriusan dan motivasi mereka dalam melaksanakan praktik kerja industri, sehingga mereka melaksanakannya secara santai, bahkan sering tidak masuk dan tidak memperhatikan aturan dan arahan selama pelaksanaan praktik kerja industri. Vivin (2011) juga menemukan kendala pelaksanaan praktik kerja industri yaitu kurangnya pengarahan dari instruktur di industri serta pemberian perintah yang bertubi-tubi, pekerjaan yang monoton, mahalnya biaya prakerin termasuk biaya transportasi ke lokasi prakerin maupun tambahan biaya untuk kos, kurangnya waktu prakerin yang hanya 2 bulan, materi prakerin yang berbeda antar sekolah dan di industri, namun perbedaan ini hanya sebatas pada keluasan cakupannya. Kendala guru pembimbing adalah kurangnya intensitas pertemuan antara guru pembimbing dengan instruktur dari industri, kendala lain adalah keterbatasan biaya dari sekolah, kurangnya dukungan dari pemerintah khususnya dinas pendidikan, selain itu juga ada pihak yang menganggap bahwa praktik kerja industri sebagai rutinitas saja, kendala umum ruang praktik belum bisa dikelola dengan baik. Sedangkan penelitian yang dilakukan oleh Muhyadi, Rosidah dan Siti Umi Khayatun tahun 2011 tentang tanggapan Dunia Usaha/Dunia Industri (DUDI) terhadap pelaksanaan praktik kerja industri di SMK Negeri 1 Depok memperoleh hasil bahwa tanggapan DUDI terhadap pelaksanaan prakerin SMKN 1 Depok Sleman secara keseluruhan baik. Hanya beberapa hal yang perlu diperbaiki adalah faktor job deskripsi instruktur perlu diperjelas kepada seluruh instruktur, kehadiran guru pembimbing perlu ditingkatkan, dan koordinasi antara sekolah dan DUDI perlu lebih diintensifkan.

Beberapa penelitian tentang pelaksanaan praktik kerja industri sebagaimana disebutkan di atas terdapat hasil yang berbeda-beda antara satu sekolah/lokasi dengan sekolah/ lokasi yang lain. Ada yang menemukan bahwa pelaksanaan praktik kerja industri disuatu sekolah telah berjalan dengan baik dan pelaksanaannya telah efektif, ada pula yang menemukan kendala-kendala yang terjadi selama pelaksanaan paktik kerja industri disamping hal-hal positif . Dari penemuan-penemuan tersebut muncul rekomendasi yang berbedabeda pula sesuai dengan kondisi pelaksanaan praktik kerja industri di lapangan. Semua rekomendasi tentunya mengacu pada keefektifan pelaksanaan praktik kerja industri pada masing-masing sekolah untuk periode pelaksanaan berikutnya. Hal inilah yang mendorong penulis untuk mengadakan penelitian tentang pelaksanaan praktik kerja industri untuk program keahlian Teknik Pemesinan SMK se-Kabupaten Kulon Progo. Pertanyaan penelitian adalah: 1) Bagaimanakah pengelolaan praktik kerja industri pada Program Keahlian Teknik Pemesinan SMK se-Kabupaten Kulon Progo?. 2) Seberapa besar manfaat praktik kerja industri pada Program Keahlian Teknik Pemesinan SMK se-Kabupaten Kulon Progo?

Adapun tujuan penelitian ini adalah :1) Untuk mengetahui perencanaan, pelaksanaan, evaluasi dan manfaat praktik kerja industri program Keahlian Teknik Pemesinan SMK seKabupaten Kulon Progo,

Hasil penelitian ini diharapkan memberikan manfaat praktis kepada beberapa pihak yang terkait dengan pelaksanaan praktik kerja industri. Adapun manfaat tersebut adalah: 1) Bagi penentu kebijakan di sekolah adalah sebagai refleksi diri terhadap pelaksanaan praktik kerja industri, dan dapat dijadikan sebagai ba- 
han pertimbangan pada pelaksanaan yang akan datang agar pelaksanaan praktik kerja industri semakin memberikan kontribusi terhadap ketercapaian tujuan pendidikan menengah kejuruan. 2) Bagi industri, dapat dijadikan sebagai dokumen dalam pelaksanaan praktik kerja industri, sebagai bahan introspeksi bagi pelaksanaan pratik kerja industri periode berikutnya. Selain itu diharapkan pihak industri akan lebih memahami kebermaknaan dari pelaksanaan praktik kerja industri. 3) Bagi peserta didik, peserta didik akan lebih mengetahui dan memahami apa yang seharusnya mereka lakukan pada saat melaksanakan praktik kerja industri. Peserta didik juga lebih mengetahui manfaat dari pelaksanaan praktik kerja industri. Dengan memahami hal-hal yang berkaitan dengan praktik kerja industri diharapkan peserta didik akan melaksanakan praktik kerja industri secara optimal.

Selain beberapa manfaat sebagaimana disebutkan di atas, hasil penelitian ini juga diharapkan menjadi sumbangsih pemikiran bagi penelitian selanjutnya yang masih berhubungan dengan pelaksanaan maupun pengelolaan praktik kerja industri di Sekolah Menengah Kejuruan (SMK).

\section{METODE PENELITIAN}

\section{Jenis penelitian}

Jenis penelitian yang digunakan untuk menjawab pertanyaan pada penelitian ini adalah penelitian dengan metode survey. Penelitian survey termasuk dalam kategori penelitian kuantitatif. Berdasarkan rancangan waktu, metode penelitian ini termasuk metode cross sectional survey (http/ /www. ischool. utexas. edu/-palmquis/ courses /survey. Html \#Design).

\section{Waktu dan Tempat Penelitian}

Penelitian ini dilaksanakan di SMK yang mempunyai program keahlian Teknik Pemesinan se-Kabupaten Kulon Progo dan industri-industri dimana siswa Program Keahlian Teknik Pemesinan melakukan praktik kerja industri. SMK yang dimaksud adalah: SMK Negeri 2 Pengasih, SMK Negeri 1 Nanggulan dan SMK Bopkri Sentolo. Waktu penelitian bulan Maret sampai April tahun 2013. Sedangkan industri yang digunakan untuk mengambil data penelitian adalah industri yang pada tahun pelajaran 2012/2013 menerima siswa praktik kerja industri.

\section{Subjek Penelitian}

Subyek penelitian dalam penelitian ini adalah Wakil Kepala Sekolah bidang Humas/ Hubin, guru pembimbing prakerin, pembimbing prakerin dari industri dan peserta didik/ siswa yang melaksanakan praktik kerja industri tahun pelajaran 2012/2013. Penentukan responden penelitian menggunakan teknik sampling random sampling untuk populasi siswa dan sampling jenuh untuk populasi Wakil Kepala Sekolah, guru pembimbing dan pembimbing industri. Penentuan jimlah sampel menggunakan daftar penentuan jumlah sampel menurut Isaac dan Michael dengan kesalahan $5 \%$.

\section{Prosedur}

Sebagaimana disebutkan di atas bahwa jenis penelitian ini adalah penelitian survey. Berdasarkan rancangan waktu penelitian ini termasuk dalam kategori cross sectional survey. Adapun prosedur dalam penelitian ini adalah sebagai berikut: menentukan masalah penelitian, membuat desain survey, mengembangkan instrumen survey, menentukan sampel, menguji coba instrumen, mengumpulkan data, memeriksa data (editing), mengkode data, memasukan data (data entry), pengolahan dan analisis data, interpretasi data, membuat kesimpulan dan saran/rekomendasi.

\section{Data, Instrumen dan Teknik Pengumpulan Data}

Data penelitian terbagi menjadi dua jenis data yaitu data ordinal dan data interval. Data ordinal diperoleh dari dokumen praktik kerja industri yang dimiliki sekolah, sedangkan data interval diperoleh dari responden penelitian berupa persepsi mereka tentang pelaksanaan praktik kerja industri dan manfaat yang dirasakan responden dari pelaksanaan praktik kerja industri. Responden penelitian terdiri dari Wakil Kepala Sekolah Bidang Humas dan Hubin, guru pembimbing praktik kerja industri, siswa dan pembimbing dari industri. 
Tabel 1. Rangkuman kriteria skor hasil penelitian berdasarkan skor ideal

\begin{tabular}{llcccc}
\hline \multirow{2}{*}{ No } & \multirow{2}{*}{ Data responden } & \multicolumn{4}{c}{ Kategori } \\
\cline { 3 - 6 } & & Sangat tinggi & Tinggi & Sedang & Rendah \\
\hline 1 & Siswa & $>321,75$ & $248-321,75$ & $173,3-247,9$ & $<173,3$ \\
2 & Guru pembimbing & $>48,75$ & $37,5-48,75$ & $26,25-37,4$ & $<26,25$ \\
3 & Pembimbing industri & $>58,5$ & $45-58,5$ & $31,5-45$ & $<31,5$ \\
\hline 4 & WKS Humas Hubin & $>9,75$ & $7,5-9,75$ & $5,25-7,5$ & $<5,25$ \\
\hline
\end{tabular}

Instrumen penelitian ini menggunakan kuesioner dan pedoman dokumentasi. Kuesioner digunakan untuk menjaring data dari responden yang berkaitan dengan persepsi mereka tentang pelaksanaan praktik kerja industri dan manfaat yang mereka rasakan dari pelaksanaan praktik kerja industri tersebut. Instrumen kuesioner dibat dalam bentuk penilaian model skala Likert dengan empat alternatif jawaban. Pedoman dokumentasi digunakan untuk menjaring data yang berkaitan dengan perencanaan praktik kerja industri, respondennya adalah Wakil Kepala Sekolah Biddang Humas dan Hubin.

\section{Teknik Analisis Data}

Analisis data yang digunakan pada penelitian ini adalah analisis data dengan metode analisis deskriptif. Analisis data deskriptif digunakan untuk mendeskripsikan data apa adanya dan tidak digunakan untuk mengambil kesimpulan statistik (Endang Mulyatiningsih, 2011: 38). Kebanyakan statistik deskriptif yang umum dipakai pada penelitian survey adalah mean, varian, standar deviasi, range dan prosentase distribusi (Edy Suhardono, 2001: 79).

Hasil analisis data secara deskriptif pada penelitian ini akan dilaporkan dalam bentuk mean, mode, median, standar deviasi, skewness, kurtosis, nilai minimum dan nilai maksimum. Untuk menginterpretasikan hasil penelitian, digunakan klasifikasi kecenderungan rerata skor ideal sebagai pembanding, yang dikelompokkan menjadi empat klasifikasi (Saifudin Azwar, 2008: 108) sebagai berikut.

$$
\begin{array}{ll}
>(\mathrm{Mi}+1,5 \mathrm{Sdi}) & \text { : sangat tinggi } \\
>\text { Mi sampai }(\mathrm{Mi}+1,5 \mathrm{Sdi}) & : \text { tinggi } \\
(\mathrm{Mi}-1,5 \mathrm{Sdi}) \text { sampai } \mathrm{Mi} & \text { : cukup } \\
<\mathrm{Mi}-1,5 \mathrm{Sdi}) & \text { : rendah }
\end{array}
$$

Harga Mi dan SDi diperoleh menggunakan rumus berikut. Mean ideal $=1 / 2$ (skor maksimum ideal - skor minimum ideal)

SD ideal $=1 / 6$ (skor maksimum ideal skor minimum ideal). Rangkuman kriteria skor ideal ada pada tabel 1 .

\section{HASIL PENELITIAN DAN PEMBAHASAN}

Kegiatan Perencanaan Praktik Kerja Industri. Yang dimaksud dengan kegiatan perencanaan praktik kerja industri disini adalah kegiatan-kegiatan yang berkaitan dengan praktik kerja industri yang dilaksanakan oleh sekolah sebelum praktik kerja industri dilaksanakan. Ringkasan hasil skor kegiatan perencanaan dapat dilihat pada tabel 2. Kegiatan-kegiatan tersebut adalah: a) Penetapan struktur organisasi praktik kerja industri. Hasil penelitian menunjukkan bahwa semua atau sebesar 100\% SMK se-Kabupaten Kulon Progo yang memiliki Program Keahlian Teknik Pemesinan telah menetapkan stuktur organisasi dalam rangka pelaksanaan praktik kerja industri. Dengan adanya struktur organisasi maka personil yang terlibat dalam organisasi tersebut dapat mengetahui kegiatan atau pekerjaan yang harus ia laksanakan, berkonsultasi atau bertanggungjawab pada siapa, sehingga proses kerja sama menuju tercapai tujuan praktik industri dapat terwujud sesuai dengan perencanaan yang telah ditetapkan sebelumnya. b) Pembuatan surat keputusan panita pelaksana. Hasil penelitian menunjukkan bahwa semua atau sebesar 100\%SMK se-Kabupaten Kulon Progo yang memiliki Program Keahlian Teknik Pemesinan membuat surat keputusan panitia pelaksana program praktik kerja industri. Dengan adanya surat keputusan yang dibuat oleh sekolah diharapkan personil sekolah yang terlibat dalam 
Tabel 2. Hasil skor variabel perencanaan prakerin

\begin{tabular}{clccc}
\hline No & Dokumen & Skor & Skor ideal & Prosentase \\
\hline 1 & Struktur Organisasi prakerin & 3 & 3 & $100 \%$ \\
2 & SK pengelola prakerin & 3 & 3 & $100 \%$ \\
3 & Pembagian tugas/job diskripsi pengelola prakerin & 2 & 3 & $66,67 \%$ \\
4 & Naskah kerja sama dengan industri tempat prakerin & 3 & 3 & $100 \%$ \\
5 & Buku Pedoman Prakerin & 2 & 3 & $66,67 \%$ \\
6 & Buku jurnal untuk siswa, guru pembimbing dan & 3 & 3 & $100 \%$ \\
& pembimbing pakerin & & & \\
7 & Daftar DUDI tempat prakerin & 3 & 3 & $100 \%$ \\
8 & Daftar siswa peserta prakerin & 3 & 3 & $100 \%$ \\
9 & Daftar guru pembimbing & 3 & 3 & $100 \%$ \\
10 & Jadwal prakerin & 3 & 3 & $100 \%$ \\
11 & Standar kualifikasi guru pembimbing & 1 & 3 & $33,33 \%$ \\
12 & Kriteria DUDI sebagai tempat prakerin & 3 & 3 & $100 \%$ \\
13 & Pembekalan prakerin & 3 & 3 & $100 \%$ \\
\hline & Total skor & $\mathbf{3 5}$ & $\mathbf{3 9}$ & $\mathbf{R a t a - r a t a}$ \\
\end{tabular}

kegiatan praktik kerja industri lebih maksimal dalam bekerja sehingga kegiatan praktik kerja industri juga akan berhasil maksimal sesuai dengan yang diharapkan. c) Naskah kerja sama dengan institusi pasangan. Hasil penelitian menunjukkan bahwa semua atau sebesar 100\% SMK se-Kabupaten Kulon Progo yang memiliki Program Keahlian Teknik Pemesinan memiliki Naskah kesepakatan kerja sama Memorandum of Understanding $(\mathrm{MoU})$ dengan industri sebagai tempat pelaksanaan praktik kerja industri. Namun dari hasil studi dokumen, belum semua industri yang dijadikan tempat praktik kerja industri bersedia menandatangai naskah kerja sama dengan sekolah, dengan alasan tidak mau terikat dengan perjanjian kerja sama. Industri tetap bersedia menerima siswa praktik kerja industri namun tidak bersedia menandatangani naskah kerja sama. d) Pengadaan pedoman pelaksanaan praktik kerja industri. Hasil penelitian menunjukkan bahwa dua dari tiga atau sebesar 66,67\% SMK se-Kabupaten Kulon Progo yang memiliki Program Keahlian Teknik Pemesinan membuat pedoman pelaksanaan prakerin. Agar pelaksanaan praktik kerja industri terjadi keseragaman dan memudahkan siswa, guru pembimbing maupun pembimbing dari industri maka buku pedoman praktik kerja industri perlu untuk dibuat disosialisasikan kepada siswa dan guru pembimbing. Buku pedoman juga dapat di- manfaatkan untuk mengevaluasi sejauh mana kegiatan praktik kerja industri sudah sesuai dengan yang direncanakan. e) Pengadaan buku jurnal praktik kerja industri.

Hasil penelitian menunjukkan bahwa semua SMK atau sebesar 100\% SMK se-Kabupaten Kulon Progo yang memiliki Program Keahlian Teknik Pemesinan membuat buku jurnal untuk siswa yang melaksanakan praktik kerja industri. Buku jurnal yang telah diisi dengan lengkap oleh siswa akan memudahkan siswa untuk menyusun laporan pelaksanaan praktik kerja industri. Selain itu juga memudahkan pembimbing untuk memonitor keaktifan siswa selama melaksanakan praktik kerja industri. Buku jurnal juga dapat digunakan sebagai acuan untuk mengevaluasi apakah pekerjaan di industri dimana siswa melaksanakan praktik kerja industri sesuai dengan program keahliannya. f) Pembuatan daftar industri tempat praktik kerja industri

Hasil penelitian menunjukkan bahwa semua atau sebesar 100\% SMK se-Kabupaten Kulon Progo yang memiliki Program Keahlian Teknik Pemesinan telah membuat daftar industri tempat praktik kerja industri bagi siswasiswanya. Pembuatan daftar industri tempat melaksanakan praktik kerja industri memudahkan guru pembimbing dalam memantau pelaksanakaan praktik kerja industri.g) Pembuatan 
Tabel 3. Rangkuman skor kegiatan proses praktik kerja industri

\begin{tabular}{|c|c|c|c|c|}
\hline \multirow[t]{2}{*}{ No } & \multirow[t]{2}{*}{ Indikator } & \multicolumn{3}{|c|}{$\begin{array}{c}\text { Rata-rata Skor Data dari Instru- } \\
\text { men }\end{array}$} \\
\hline & & $\mathbf{A}$ & B & $\mathbf{C}$ \\
\hline 1. & Kesiapan siswa & 318 & - & - \\
\hline 2. & Kesiapan industri & - & - & 51 \\
\hline 3. & Pengalaman membimbing & - & 54 & 53 \\
\hline \multirow[t]{7}{*}{4.} & Kegiatan pembimbingan & & & \\
\hline & 4.1 sikap pembimbing & 333 & - & - \\
\hline & 4.2 pemeriksaan jurnal kegiatan & 311 & 31 & 63 \\
\hline & 4.3 frekuensi monitoring & 315 & 48 & - \\
\hline & 4.4 memotivasi siswa & 348 & 53 & 51 \\
\hline & 4.5 membantu siswa & - & 52,5 & - \\
\hline & 4.6 mengisi buku monitoring & & 50 & \\
\hline 5. & Metode pembimbingan & 278 & - & 65 \\
\hline 6. & Kesesuaian pekerjaan & 316 & 43 & - \\
\hline 7. & Pengisian jurnal kegiatan siswa & 342 & - & - \\
\hline 8. & Hubungan peserta dengan pegawai & 319 & - & 53 \\
\hline 9. & Kedisiplinan & - & - & 47,5 \\
\hline 10. & Tanggung jawab & - & - & 48,33 \\
\hline 11. & Inisiatif & - & - & 50,5 \\
\hline 12. & Kerja sama & - & - & 56,33 \\
\hline 13. & Masukan industri kepada sekolah & - & - & 44,67 \\
\hline \multicolumn{2}{|c|}{ Rata-rata } & 320 & 41,43 & 48,7 \\
\hline
\end{tabular}

daftar peserta praktik kerja industri. Hasil penelitian menunjukkan bahwa semua atau sebesar 100\% SMK se-Kabupaten Kulon Progo yang memiliki Program Keahlian Teknik Pemesinan telah membuat daftar peserta praktik kerja industri.

Ada kalanya tidak semua siswa diterjunkan secara bersama-sama untuk melaksanakan praktik kerja industri. Seperti yang terjadi di SMK Negeri 2 Pengasih, siswa yang melaksanakan praktik kerja industri dibagi menjadi dua gelombang, yaitu setengah kelas melaksanakan pada gelombang satu dan setengah kelas berikutnya melaksanakan praktik kerja industri pada gelombang dua. Sedangkan yang terjadi di SMK Negeri 1 Nanggulan dan SMK Bopkri Sentolo, pelaksanaan praktik kerja industri mengambil satu waktu, artinya siswa diterjunkan secara bersama-sama. Dengan demikian data peserta praktik kerja industri menjadi dokumen yang sangat penting. h) Pembuatan daftar guru pembimbing. Hasil penelitian menunjukkan bahwa semua atau sebesar 100\% SMK se-Kabupaten Kulon Progo yang memiliki Program Keahlian Teknik Pemesinan telah membuat daftar guru pembimbing praktik kerja industri. i) Pembuatan jadwal praktik kerja industri. Hasil penelitian menunjukkan bahwa semua atau sebesar 100\% SMK se-Kabupaten Kulon Progo yang memiliki Program Keahlian Teknik Pemesinan membuat jadwal pelaksanaan praktik kerja industri. Walaupun tidak ada ketentuan dikelas berapa praktik kerja industri dilaksanakan, namun pelaksanaannya harus dijadwal agar berjalan dengan tertib. Data hasil penelitian yang dibuktikan dengan dokumen yang ada, ketiga sekolah aatau sebesar $100 \%$ telah membuat jadwal pelaksanaan praktik kerja industri. Dengan jadwal yang jelas, maka sekolah maupun industri dapat merencanakan dengan baik hal-hal yang berkaitan dengan pelaksanaan praktik kerja industri. j) Penetapan standar kualifikasi guru pembimbing praktik kerja indsutri. Hasil penelitian menunjukkan bahwa satu dari tiga atau sebesar 33,33\% SMK se-Kabupaten Kulon Progo yang memiliki Program Keahlian Teknik Pemesinan yang menetapkan standar kualifikasi untuk 
guru pembimbing praktik kerja industri. Tidak semua guru di Sekolah Menengah Kejuruan bisa menjadi guru pembimbing praktik kerja industri. Sebagai contoh, menjadi kurang pas apabila guru agama atau guru olah raga menjadi guru pembimbing praktik kerja industri. Maka sekolah harus menetapkan standar kualifikasi guru pembimbing. Kompeteni guru pembimbing paling tidak harus sesuai dengan progam keahlian yang dimiliki siswa. Hal ini bertujuan agar apabila terjadi kesulitan siswa yang berhubungan dengan kompetensi teknis, guru pembimbing bisa memberikan solusi dari permasalahan yang dihadapi. Artinya penetapan standar kualifikasi guru pembimbing praktik kerja industri perlu untuk dibuat. k) Penetapan kriteria industri sebagai tempat praktik kerja industri. Hasil penelitian menunjukkan bahwa semua atau sebesar $100 \%$ SMK se-Kabupaten Kulon Progo yang memiliki Program Keahlian Teknik Pemesinan telah menetapkan kriteria industri sebagai tempat pelaksanaan praktik kerja industri. Penentuan kriteria industri juga dimaksudkan agar tujuan praktik kerja industri tercapai dengan baik. Secara umum industri yang dapat digunakan sebagai tempat praktik kerja industri adalah yang sesuai dengan program keahlian siswa baik yang berskala nasional, regional bahkan perusahaan yang berskala kecil sekalipun. Karena dalam kenyataannya justru perusahaan yang berskala kecil lebih memberikan perhatian pada pembelajaran. Seharusnya dokumentasi penetapan kriteria industri sebagai tempat pelaksanaan praktik kerja industri dibuat dan disosialisasikan kepada guru pembimbing dan siswa agar pada saat mencari tempat praktik kerja industri sesuai dengan kriteria tersebut. Kesesuaian tempat praktik kerja industri dengan program keahlian siswa sangat menentukan ketercapaian tujuan praktik kerja industri. 1) Pelaksanaan pembekalan. Hasil penelitian menunjukkan bahwa semua atau sebesar $100 \%$ SMK se-Kabupaten Kulon Progo yang memiliki Program Keahlian Teknik Pemesinan mengadakan pembekalan sebelum menerjunkan siswa-siswanya untuk melaksanakan praktik kerja industri.

Dari keterangan yang diberikan oleh Wakil Kepala Sekolah bidang Humas Hubin ketiga sekolah, pembekalan yang dilaksanakan sebelum nenerjunkan siswa ke industri dilaku- kan oleh guru-guru yang terlibat dalam program praktik kerja industri. Disarankan kepada sekolah, hendaknya dalam melaksanakan pembekalan melibatkan industri sebagai pemateri, sehingga gambaran yang diperoleh siswa saat pembekalan mendekati sama dengan keadaan pada saat pelaksanaan praktik kerja industri.

\section{Kegiatan Proses Pelaksanaan Praktik Kerja Industri}

Rangkuman skor hasil penelitian yang berkaitan dengan proses prakerin dapat dilihat pada tabel 3. Kegiatan-kegiatan proses pelaksanaan adalah sebagai berikut: 1) Kesiapan siswa melaksanakan prakerin.Hasil penelitian menunjukkan bahwa skor rata-rata kesiapan siswa melaksanakan praktik kerja industri sebesar 318. Skor ini berada diantara 248 sampai dengan 321,75 , artinya kesiapan siswa secara umum untuk melaksanakan praktik kerja industri termasuk dalam kategori tinggi. Kesiapan siswa akan mempengaruhi ketercapaian tujuan, disamping faktor-faktor yang lain. 2) Hasil penelitian menunjukkan bahwa skor ratarata kesiapan industri menerima praktik kerja industri sebesar 51 . Angka 51 berada diatas batas minimal kategori tinggi sehingga dapat diartikan bahwa industri-industri yang digunakan sebagai tempat praktik kerja industri oleh SMK Negeri 2 Pengasih, SMK Negeri 1 Nanggulan dn SMK Bopkri Sentolo bersedia dan siap untuk digunakan sebagai tempat praktik kerja industri. Sesuai dengan penafsiran yang ada pada skor rata-rata ideal sebagaimana disebutkan di atas, mode sebesar 3,00 juga menunjukkan bahwa sebagian besar industri telah siap melaksanakan praktik kerja industri. 3) Pengalaman membimbing. Data pengalaman membimbing dijaring dari guru pembimbing dan pembimbing industri. Hasil penelitian menunjukkan bahwa skor pengalaman membimbing guru pembimbing sebesar 54 dan pembimbing industri sebesar 53. Dari hasil perolehan skor rata-rata dapat disimpulkan bahwa pengalaman membimbing baik pembimbing dari sekolah maupun dari industri berdasarkan instrumen, rata-rata lebih dari tiga tahun. Penafsiran ini didukung oleh hasil perhitungan median sebesar 4,00, mode atau nilai yang paling banyak muncul yaitu 4 , skewness yang bernilai negative. 3) Kegiatan pembimb- 
ingan: a) Sikap pembimbing.Data dijaring dari responden siswa. Hasil penelitian menunjukkan bahwa skor rata-rata sikap pembimbing adalah 333. Mengacu pada kriteria skor pada tabel 7 di atas maka sikap pembimbing berada pada kategori sangat tinggi. Skewness yang bernilai negatif juga menunjukkan bahwa responden lebih banyak yang memberikan tanggapan diatas nilai median. Hal ini dapat ditafsirkan bahwa sikap pembimbing industri sangat kooperatif terhadap siswa. b) Pemeriksaan jurnal kegiatan.Hasil penelitian menunjukkan bahwa skor pemeriksaan jurnal berdasakan persepsi siswa sebesar 311, skor berdasarkan guru pembimbing sebesar 31 dan skor berdasarkan pembimbing industri sebesar 63. c) Frekuensi monitoring. Hasil penelitian menunjukkan bahwa skor frekuensi monitoring guru pembimbing menurut persepsi siswa sebesar 315, dan skor menurut guru pembimbing rata-rata sebesar 48 . Sebanyak $22 \%$ siswa berpendapat bahwa guru pembimbing selalu memonitor pelaksanaan praktik kerja industri. Skewness bernilai negatif berarti bahwa menurut persepsi sebagian besar siswa pembimbing sekolah sering melaksanakan monitoring. Yang perlu menjadi perhatian adalah bahwa $19 \%$ siswa berpendapat guru pembimbing tidak selalu memonitor pelaksanaan praktik kerja industri. d) Memotivasi siswa. Hasil penelitian menunjukkan bahwa skor guru pembimbing memotivasi siswa menurut persepsi siswa sebesar 348, skor memotivasi menurut guru pembimbing sebesar 53 dan skor memotivasi menurut pembimbing industri sebesar 51. Berdasarkan hasil di atas dapat disimpulkan bahwa pembimbing industri selalu memotivasi siswa bekerja lebih baik dan mentaati peraturan industri. e) Metode pembimbingan. Hasil penelitian menunjukkan bahwa skor metode pembimbingan menurut persepsi siswa sebesar 278 , skor menurut pembimbing industri ratarata sebesar 65. Berdasarkan kriteria skor ideal, skor ini termasuk dalam kategori tinggi. Pembimbing industri memberi kesempatan kepada peserta praktik kerja industri untuk konsultasi dan berdiskusi dalam mengerjakan tugas yang diberikan oleh industri. f) Kesesuaian pekerjaan dengan program keahlian siswa. Diantara konsep yang merupakan bagian penting dalam pelaksanaan praktik kerja industri adalah kesesuaian antara program keahlian siswa dengan bidang usaha/jenis pekerjaan di industri. Kesesuaian keduanya akan sangat membantu dalam pencapaian tujuan pelaksanaan praktik kerja industri.Hasil penelitian menunjukkan bahwa skor kesesuaian pekerjaan dengan program keahlian siswa menurut siswa rata-rata sebesar 315,5 dan skor menurut guru pembimbing sebesar 43. g) Hubungan peserta prakerin dengan pegawai. Hasil penelitian menunjukkan bahwa skor hubungan peserta praktik kerja industri dengan pegawai menurut persepsi siswa sebesar 319 dan skor menurut pembimbing industri sebesar 53. Bila dibandingkan dengan skor ideal, skor 319 termasuk dalam kategori tinggi. Secara detail menurut hasil penelitian dengan responden siswa, persepsi siswa bahwa hubungan antara karyawan dengan peserta praktik kerja industri berjalan dengan baik, $41 \%$ menyatakan sangat setuju, 54\% menyatakan setuju, 3\% menyatakan kurang setuju dan $2 \%$ menyatakan tidak setuju. h) Kedisplinan. Hasil penelitian menunjukkan bahwa skor kedisiplinan siswa pembimbing industri rata-rata sebesar 47,5. Berdasarkan kriteria skor ideal untuk responden pembimbing industri sebagai pembanding skor ini termasuk dalam kategori tinggi. Walaupun rata-rata termasuk dalam kategori tinggi, namun kalau dilihat pada tabel 25 , sebanyak 39\% responden industri menyatakan tingkat kedisiplinan siswa berada pada kategori sedang dan $11 \%$ responden mengatakan kedisiplinan siswa termasuk rendah. i) Tanggung jawab.Hasil penelitian menunjukkan bahwa skor tanggung jawab siswa menurut persepsi pembimbing industri rata-rata sebesar 48,33. Berdasarkan kriteria skor ideal responden pembimbing industri, sebagaimana terdapat pada tabel 7, skor ini termasuk dalam kategori tinggi karena terletak antara 45 sampai dengan 58,5. $6 \%$ responden menyatakan bahwa tanggung jawab siswa sangat tinggi, $61 \%$ responden menyatakan bahwa tanggung jawab siswa saat melaksanakan praktik kerja industri termasuk tinggi dan sebanyak 33\% responden menyatakan sedang. j) Inisiatif. Hasil penelitian menunjukkan bahwa skor inisiatif siswa menurut persepsi pembimbing industri rata-rata sebesar 50,5 yang beraa pada kategori tinggi. ketika mengalami kesulitan dalam menyele- 
saikan pekerjaan di industri siswa bertanya pada karyawan, 4 responden atau $22 \%$ menyatakan siswa bertanya pada teman dan 2 responden atau $11 \%$ menyatakan siswa diam saja. Responden industri tidak ada yang menyatakan siswa menyelesaikan sendiri ketika mengalami kesulitan dalam bekerja. Hal ini sesuai dengan aturan yang ditekankan industri agar bertanya apabila mengalami kesulitan dalam menyelesaikan pekerjaan. k) Kerja sama. Hasil penelitian menunjukkan bahwa skor kerja sama menurut persepsi pembimbing industri rata-rata sebesar 56,33. Dengan mengacu pada kriteria skor ideal, untuk data hasil penelitian dengan responden pembimbing industri skor 56,3 termasuk termasuk dalam kategori tinggi. Untuk menyelesaikan pekerjaan dalam proses produksi, industri sangat menekankan kerja sama. Tanpa kerja sama yang harmonis antar pegawai, proses produksi akan mengalami hambatan yang berarti kerugian bagi industri. Maka dalam pelaksanaan praktik kerja industri kerja sama juga sangat ditekankan pada para siswa. 1) Masukan industri. Masukan industri yang diungkap dalam penelitian ini adalah masukan yang berkaitan dengan kekurangan siswa saat melaksanakan praktik kerja industri, masukan untuk penyempurnaan kurikulum dan masukan untuk penyempurnaan pelaksanaan praktik kerja industri. Masukan industri yang berkaitan dengan kekurangan siswa saat melaksanakan praktik kerja industri mempunyai skor 50, mengacu pada kriteria skor ideal, skor ini termasuk dalam kategori tinggi. Dengan skor tinggi berarti industri sering memberikan masukan pada sekolah melalui guru pembimbing mengenai kekurangan-kekurangan siswa saat melaksanakan praktik kerja industri. Masukan industri yang berkaitan dengan penyempurnaan kurikulum mempunyai skor 47, mengacu pada kriteria skor ideal sebagaimana terdapat pada tabel 7, skor ini termasuk dalam kategori tinggi.

\section{Evaluasi Praktik Kerja Industri}

Evaluasi praktik kerja industri dikelompokkan menjadi dua yaitu evaluasi terhadap siswa yang berkaitan dengan pembelajaran praktik industri yang dilakukan oleh sekolah dan industri serta evaluasi program praktik kerja industri yang dilakukan oleh sekolah. Hasil penelitian menunjukkan bahwa skor evaluasi terhadap siswa yang dilakukan industri sebesar 72. Skor 72 adalah skor ideal tertinggi, artinya semua industri melakukan evaluasi terhadap kompetensi siswa selama melaksanakan praktik kerja industri. Skor evaluasi yang dilakukan sekolah terhadap siswa sebesar 2 atau sebesar $66,67 \%$ yang berarti tidak semua sekolah melakukan evaluasi terhadap siswa yang melakasanakan praktik kerja industri. Sedangkan evaluasi program praktik kerja industri yang dilakukan sekolah mempunyai skor sebesar 7. Skor 7 apabila dibandingkan dengan kriteria skor ideal termasuk dalam kategori rendah. Hal ini berarti bahwa SMK se-Kabupaten Kulon Progo yang mempunyai Program Keahlian Teknik Pemesinan jarang melakukan evaluasi program praktik kerja industri.

\section{Manfaat Praktik Kerja Industri}

Manfaat praktik kerja industri dikelompokkan menjadi tiga yaitu manfaat yang dirasakan siswa, manfaat yang dirasakan sekolah dan manfaat yang dirasakan industri. Hasil penelitian menunjukkan bahwa manfaat yang dirasakan siswa mempunyai skor rata-rata sebesar 340,17, skor ini apabila dibandingkan dengan skor ideal termasuk dalam kategori tinggi, artinya siswa merasakan manfaat yang tinggi dengan adanya praktik kerja industri. Manfaat yang dirasakan sekolah mempunyai skor rata-rata sebesar 57,5, skor ini juga termasuk dalam kategori tinggi. Manfaat yang dirasakan industri mempunyai skor rata-rata sebesar 53,33 yang berada pada kategori tinggi. Adanya manfaat yang dirasakan para personil yang terlibat dalam pelaksanaan praktik kerja industri merupakan indikasi yang baik guna peningkatan hubungan kerjasama saling menguntungkan antara sekolah dengan industri.

\section{SIMPULAN DAN SARAN}

\section{Simpulan}

Berdasarkan hasil pembahasan maka penelitian ini dapat menyimpulkan hal-hal berikut. 1) Berkaitan dengan pengelolaan praktik kerja industri. Sebesar 89,74\% kegiatan perencanaan praktik kerja industri telah 
dilaksanakan. Beberapa hal yang ditemukan dan perlu untuk ditindaklanjuti dalam perencanaan adalah: a) Sebesar 33,33\% sekolah belum membuat pembagian tugas bagi personil yang terlibat dalam pengelolaan praktik kerja industri. b) Sebesar 33,33\% sekolah belum membuat buku pedoman praktik kerja industri. c) Sebesar $66,67 \%$ sekolah belum menetapkan standar kualifikasi guru pembimbing praktik kerja industri. 2) Kegiatan proses praktik kerja industri menurut persepsi siswa berjalan dengan baik. Skor rata-rata yang diperoleh sebesar 320, termasuk kategori tinggi . Kegiatan proses praktik kerja industri menurut persepsi guru pembimbing berjalan dengan baik. Skor rata-rata yang diperoleh yaitu sebesar 41,43 termasuk kategori tinggi. Kegiatan proses praktik kerja industri menurut persepsi pembimbing industri berjalan dengan baik. Skor rata-rata yang diperoleh yaitu sebesar 48,7 termasuk kategori tinggi. Beberapa hal yang perlu menjadi perhatian dalam kegiatan proses praktik kerja industri adalah: a) Frekuensi pemeriksaan jurnal kegiatan harian siswa oleh guru pembimbing, $20 \%$ responden melakukannya lebih dari empat minggu sekali. c) Menurut persepsi siswa yaitu sebesar $19 \%$, guru pembimbing kurang dalam melakukan monitoring kegiatan praktik kerja industri. d) Adanya ketidakseragaman frekuensi monitoring antar guru pembimbing dalam satu sekolah, $20 \%$ responden melakukan monitoring dua minggu sekali, $27 \%$ responden melakukan monitoring tiga minggu sekali dan $53 \%$ responden melakukan monitoring empat minggu sekali. e) Menurut persepsi siswa yaitu sebesar 53\% menyatakan bahwa guru pembimbing jarang memotivasi siswa selama pelaksanaan praktik kerja industri. f) Sebesar $47 \%$ industri tidak pernah memberikan masukan kepada sekolah untuk penyempurnaan pelaksanaan praktik kerja industri. 3) Kegiatan evaluasi pembelajaran praktik kerja industri terhadap siswa dilakukan oleh semua industri. Sebesar 66,67\% SMK melaksanakan kegiatan evaluasi pembelajaran praktik kerja industri terhadap siswa. SMK tersebut adalah SMK Negeri 2 Pengasih dan SMK Bopkri Sentolo. SMK Negeri 1 Nanggulan tidak melaksanakan evaluasi pembelajaran praktik kerja industri. Kegiatan evaluasi program praktik kerja industri selalu dilakukan oleh SMK Negeri 2
Pengasih, SMK Negeri 1 Nanggulan kadangkadang melaksanakan dan SMK Bopkri Sentolo tidak pernah melakukan evaluasi program praktik kerja industri. 4) Berkaitan dengan manfaat praktik kerja industri. Siswa merasakan manfaat yang sangat besar dari pelaksanaan praktik kerja industri. Skor rata-rata manfaat praktik kerja industri yang dirasakan oleh siswa sebesar 340,16 termasuk kategori sangat tinggi. Sekolah merasakan manfaat yang besar dengan adanya praktik kerja industri. Skor rata-rata manfaat praktik kerja industri yang dirasakan sekolah sebesar 8,88 termasuk dalam kategori tinggi. Industri merasakan manfaat yang besar dengan adanya praktik kerja industri. Skor rata-rata manfaat praktik kerja industri yang dirasakan industri sebesar 57,5 termasuk dalam kategori tinggi.

\section{Saran}

Saran yang dapat disampaikan berkaitan dengan pelaksanaan praktik kerja industri pada Program Keahlian Teknik Pemesinan SMK se-Kabupaten Kulon Progo adalah sebagai berikut: 1) Sekolah hendaknya membuat pembagian tugas yang jelas bagi personil yang terlibat dalam pelaksanaan praktik kerja itu industri. Pembagian tugas yang jelas akan memudahkan koordinasi dan pelaksanaan praktik kerja industri. 2) Sekolah hendaknya menetapkan daftar industri yang direkomendasikan untuk pelaksanaan praktik kerja industri. Hal ini bertujuan agar industri yang dipakai sebagai tempat pelaksanaan praktik kerja industri benar-benar industri yang siap menerima siswa praktik kerja industri, selain itu juga untuk menghindari ketidaksesuaian antara program keahlian siswa dengan jenis pekerjaan di industri. 3) Bagi sekolah yang belum membuat buku pedoman pelaksanaan praktik kerja industri, sebaiknya segera untuk membuat, karena dengan buku pedoman akan memudahkan pelaksanaan praktik kerja industri bagi siapa saja yang terlibat dalamnya. 4) Sekolah sebaiknya menetapkan standar kualifikasi guru pembimbing agar proses pembimbingan dapat berjalan dengan optimal. 5) Sekolah hendaknya membuat aturan yang jelas tentang tugas dan tanggungjawab guru pembimbing, sehingga proses pembimbingan praktik kerja industri menjadi seragam. 6) Sekolah henda- 
knya menetapkan kriteria standar industri yang dapat digunakan sebagai tempat pelaksanaan praktik kerja industri, agar siswa tidak salah memilih, yang dapat mengakibatkan terjadinya hambatan dalam pelaksanaan praktik kerja industri maupun hambatan dalam mencapai tujuan praktik kerja industri. 7) Pelaksanakan pembekalan praktik kerja industri sebaiknya melibatkan industri sebagai pemateri agar siswa lebih mengetahui kondisi nyata industri secara umum, sehingga mereka lebih siap untuk melaksanakan praktik kerja industri.

\section{DAFTAR PUSTAKA}

Arifin, Zainal. (2011). Konsep dan model pengembangan kurikulum. Bandung.: PT Remaja Rosda Karya.

Azwar, Saifudin. (2008). Penyusunan skala psikologi. Yogyakarta: Pustaka Pelajar.

Boud, D. \& Solomon, N. (2001) Work based learning a new higher education? London: SRHE and Open University Press.

Budi, Tri Siswanto. (Oktober 2011). Pendidikan vokasi, work-based learning, dan penyelenggaraan program praktik pengalaman lapangan. Makalah disampaikan pada Workshop Penyusunan Buku Panduan Penulisan Laporan KP, TA, Skripsi di Fakultas Teknik Universitas Muhammadiyah Magelang.

Departemen Pendidikan Nasional. (2003). Undang-undang republik indonesia No. 20 tahun 2003 tentang sistem pendidikan nasional. Jakarta: Depdinas.

Direktorat Pembinaan Sekolah Menengah Kejuruan. (2008). Pelaksanaan prakerin. Jakarta: Dirjen Dikdasmen Depdiknas.
Edy, Suhardono. (2001). Refleksi metodologi riset panorama purvey. Jakarta: PT Gramedia Pustaka Utama.

Endang, Mulyatiningsih. (2011). Riset terapan bidang pendidikan \& teknik. Yogyakarta: UNY Pres.

Finch, C R \&. Crunkilton, John R. (1999). Curriculum development in vocational and technical educaton. Needham Heights, MA 02494: Viacom Company.

Raelin, Joseph A.. (Nov. - Dec. 1997). A Model of Work-based learning. Vol. 8, No. 6. Diambil pada tanggal 2 Pebruari 2013 dari http://www.jstor.org/ stable /2635156

Soenaryo, et al. (2002). Sejarah pendidikan teknik dan kejuruan diIndonesia. Jakarta: Direktorat Pendidikan Menengah Kejuruan.

Survey method. Diakses pada tanggal 27 Juni 2013 dari: http//www.ischool. utexas.edu/-palmquis/courses/survey. html\#Design.

Wahyu, Nurharjadmo. (Oktober 2008). Evaluasi implementasi kebijakan pendidikan sistem ganda di sekolah kejuruan. Spirit Publik, Vol 4 No 2, 215 - 228. Diambil pada tanggal 20 Desember 2012 dari http://fisip.uns.ac.id/? pilih $=$ publikasi\&mod $=$ yes\&aksi $=$ detail\&id $=112$

Wardiman, Djojonegoro. (1998). Pengembangan sumber daya manusia melalui Sekolah Menengah Kejuruan (SMK). Jakarta: PT Jaya Agung Offset. 